\title{
CORRELATION BETWEEN EXERCISE FREQUENCY AND BLOOD PRESSURE IN THE ELDERLY IN BANTUL, YOGYAKARTA
}

\author{
Sukmawati, Suryo Ediyono \\ Respati University, Yogyakarta
}

\begin{abstract}
Background: It is a well established knowledge that the risk of high blood pressure (hypertension) increases with age, but getting some exercise can make a big difference. If an individual blood pressure is already high, exercise can help the individual control it. Regular physical activity makes heart stronger. A stronger heart can pump more blood with less effort. If heart can work less to pump, the force on the arteries decreases, lowering your blood pressure. Health experts advise that regular exercise for the elderly offers great benefits, including extending lifespan. This study aimed to estimate the correlation between exercise frequency and blood pressure in the elderly in Bantul, Yogyakarta. Subjects and Method: This was a cross sectional study conducted in Bantul, Yogyakarta, on April 2-16, 2016. A sample of 38 elderlies was selected for this study by random sampling. The independent variable was exercise frequency. The dependent variable was blood pressure. The exercise frequency was measured by questionnaire. Blood pressure was measured by sphygmomanometer. The correlation between variables was measured by Pearson correlation coefficient. Results: There was negative correlation between exercise frequency and blood pressure. An elderly who often had exercise tended to have a lower blood pressure $(\mathrm{r}=0.94 ; \mathrm{p}<0.001)$.

Conclusion: Exercise is negatively correlated by blood pressure in the elderly.
\end{abstract}

Keywords: exercise, blood pressure, elderly

\section{Correspondence:}

Sukmawati. Respati University, Yogyakarta. Email:sukmayogya1809@gmail.com. 